\title{
ANALISIS TEGANGAN DAN DEFLEKSI PADA BALOK KASTELA DENGAN BUKAAN RHOMB MENGGUNAKAN METODE ELEMEN HINGGA
}

\author{
Levina Lammirta ${ }^{1}$ dan Leo S. Tedianto ${ }^{2}$ \\ ${ }^{1}$ Program Studi Sarjana Teknik Sipil, Universitas Tarumanagara, Jl. Letjen S. Parman No.1 Jakarta \\ Email:levina_lammirta@yahoo.co.id \\ ${ }^{2}$ Program Studi Sarjana Teknik Sipil, Universitas Tarumanagara, Jl. Letjen S. Parman No.1 Jakarta \\ Email: leotedi@gmail.com
}

\begin{abstract}
ABSTRAK
Baja merupakan salah satu material yang memiliki keunggulan dari segi efisiensi waktu dan pelaksanaan. Kelemahan baja dari segi biaya menimbulkan suatu rekayasa untuk meminimalisasikan penggunaannya yaitu dengan castellated beam. Castellated beam merupakan balok yang memiliki elemen pelat badan berlubang yang dibentuk dengan cara memotong badan profil dengan pola zig-zag yang dicetak menggunakan hot-rolled (cetakan panas). Belakangan ini terdapat penelitian mengenai balok kastela dengan bukaan rhomb. Berdasarkan kelebihan dan kekurangan tersebut dibutuhkan desain dimensi geometri terhadap bukaan. Parameter yang digunakan adalah tinggi profil (D) terhadap tinggi bukaan (Do) dengan jarak antara tengah dua bukaan (S) terhadap tinggi bukaan (Do) tetap. Analisis ini bertujuan untuk mengetahui pengaruh perbandingan antara tinggi profil (D) dengan tinggi bukaan (Do) pada balok kastela dengan bukaan rhomb terhadap tegangan dan defleksi dengan menggunakan metode elemen hingga dengan bantuan program SAP2000. Analisis tersebut dilakukan dengan membuat model dari balok IWF dengan ketinggian 120, 125, $130 \mathrm{~mm}$, lebar $60 \mathrm{~mm}$ dan tebal flens maupun webnya $5 \mathrm{~mm}$ dengan perbandingan D/Do 1.27, 1.33, 1.41, 1.50, 1.61, dan 1.75. Bentang balok $900 \mathrm{~mm}$, perletakan sendi rol dan beban sebesar $1000 \mathrm{~N}$ yang diletakan terpusat di tengah bentang dan dua buah beban terpusat berjarak $300 \mathrm{~mm}$ dari tengah bentang. Hasilnya menunjukkan pengaruh perbandingan D/Do terhadap tegangan lentur bervariatif dengan perbandingan D/Do 1.61 merupakan yang terlemah, begitu juga dengan tegangan geser hasilnya juga bervariatif dengan D/Do merupakan tegangan terbesar. Analisis menunjukkan bahwa semakin besar perbandingan D/DO maka tegangan yang dihasilkan semakin besar. Adanya penigkatan tegangan sebesar dua kali pada rhomb jika dibandingkan dengan balok tanpa bukaan.
\end{abstract}

Kata kunci: castellated beam with diamond shape opening (rhomb), tinggi profil (D), tinggi bukaan (Do), tegangan, defleksi, metode elemen hingga

\section{PENDAHULUAN}

Di era modern seperti sekarang ini, teknologi dituntut terus melakukan perkembangan untuk memenuhi kebutuhan hidup manusia. Infrastruktur seperti jalan, jembatan, gedung, dan lain-lain menjadi bagian penting dalam kelangsungan hidup manusia. Untuk mewujudkan hal tersebut, maka diperlukan suatu konstruksi yang kuat dan efisien dari segi waktu, pelaksanaan, dan biaya. Faktor-faktor tersebut saat ini menjadi pertimbangan dalam memilih material untuk membangun sebuah konstruksi. Salah satu konstruksi yang mampu untuk memenuhi kriteria tersebut adalah konstruksi baja. Pemanfaatan baja sebagai material dikarenakan baja memiliki keunggulan dalam hal kekuatan, kekakuan, dan daktilitas. Selain itu baja dinilai memiliki keunggulan dalam hal pelaksanaan karena lebih cepat dan efisien. Namun selain keunggulan tentunya material baja memiliki kelemahan dalam bidang konstruksi. Faktor yang dinilai sebagai kelemahan material baja yaitu biaya yang relatif lebih mahal jika dibandingkan dengan material lain. Hal ini yang menyebabkan perlunya suatu rekayasa untuk meminimalisasi penggunaan baja sehingga lebih ekonomis.

Castellated beam (balok kastela) merupakan suatu rekayasa yang telah ada cukup lama dan sering digunakan belakangan ini. Castellated beam merupakan balok yang memiliki elemen pelat badan berlubang yang dibentuk dengan cara memotong badan profil dengan pola zig-zag yang dicetak menggunakan hot-rolled (cetakan panas). Setengah bagian profil baja yang telah dipotong disambung dengan cara digeser atau dibalik (ujung kanan di las dengan ujung kiri, dan sebaliknya) sehingga membentuk lubang berbentuk polygonal. Hal ini mengakibatkan bertambahnya tinggi (h) dan tinggi daerah pemotongan (d) (Amayreh dan Saka 2005). 
Penggunaan castellated beam dalam dunia konstruksi memiliki banyak kelebihan yaitu peningkatan kekuatan dan kekakuan karena lebar profil yang lebih tinggi sehingga mengakibatkan momen inersia dan modulus section yang lebih besar dibandingkan dengan profil induk menurut Megharief (1997) dan Grunbauer tahun (2001). Berat material dari castellated beam berkurang sehingga menyebabkan berat keseluruhan struktur juga berkurang. Bukaan pada web dapat dimanfaatkan untuk duct work dan instalasi pemipaan, menggantikan cara konvensional yaitu dengan menggantungkan pipa pada balok maupun plat.

Selain kelebihan yang telah disebutkan di atas tentunya terdapat kekurangan. Akibat adanya bukaan pada pelat badan castellated beam, maka perlu ditinjau kegagalan yang terjadi pada castellated beam tersebut. Menurut M.R. Wakchaure dan A.V. Sagade (2012) kegagalan yang dapat terjadi pada castellated beam antara lain Formation Vierendeel atau Shear Mechanism, Flexural Mechanism, Lateral- Torsional- Buckling, Rupture of Welded, Web Post Buckling due to Compression.

Berdasarkan kelebihan dan kekurangan tersebut maka berbagai penelitian dilakukan untuk mencari desain yang efektif. Salah satu caranya adalah melalui desain dimensi geometri dari bukaan castellated beam. Beberapa tahun belakangan ini terdapat penelitian mengenai castellated beam dengan beberapa jenis bukaan, salah satunya adalah rhomb (diamond shaped opening). Rhomb merupakan castellated beam dengan bukaan belah ketupat. Oleh karena itu, pada penelitian ini akan dilihat bagaimana pengaruh perbandingan antara tinggi profil (D) dengan tinggi bukaan (Do) pada kondisi jarak antara tengah dua bukaan (S) dengan tinggi bukaan (Do) yang sama terhadap tegangan dan defleksi pada balok menggunakan metode elemen hingga dengan bantuan perangkat lunak Structural Analysis Program 2000.

Penelitian ini bertujuan untuk mengetahui pengaruh perbandingan antara tinggi profil (D) dengan tinggi bukaan (Do) terhadap tegangan dan defleksi dengan variasi tinggi profil (D), tinggi bukaan (Do), jarak antara tengah dua bukaan (S), dan jarak bersih antara dua bukaan (e).

\section{CASTELLATED BEAM}

Castellated beam merupakan sebuah balok yang memiliki bukaan pada bagian badan yang dibentuk dengan cara castellation. Castellation merupakan sebuah proses pemotongan bagian badan pelat dengan mengikuti sebuah pola tertentu yang kemudian disambung kembali dengan cara menggeser pelat badan tersebut lalu dilas kembali.

Pemotongan dan penyambungan kembali pada castellated beam mengakibatkan adanya pertambahan tinggi profil sehingga balok mengalami penambahan kekuatan dan kekakuan. Jika dibandingkan dengan balok aslinya, castellated beam memiliki kelebihan dalam desain dan konstruksi. Sebagai hasil dari bertambahnya tinggi profil maka adanya peningkatan rasio kedalaman terhadap berat, modulus section ( $\mathrm{Sx}$ ), dan peningkatan strong axis moment of inertia (Ix). Peningkatan ini bukan saja memungkinkan penggunaan pada bentang yang panjang, namun juga meningkatan efisiensi dari segi penghematan biaya ketika digunakan pada bentang yang panjang.

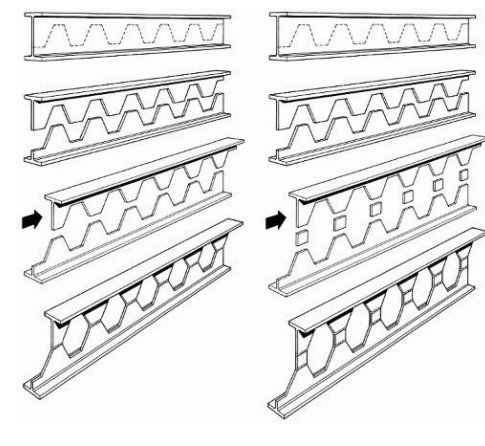

Gambar 1. Castellated Beam

\section{TEORI ELASTISITAS}

Sifat mekanik yang dimiliki material antara lain: kekuatan (strength), keliatan (ductility), kekerasan (hardness), dan kekuatan lelah (fatigue). Sifat mekanik material didefinisikan sebagai ukuran kemampuan material untuk mendistribusikan dan menahan gaya serta tegangan yang terjadi. Proses pembebanan, struktur molekul yang berada dalam ketidaksetimbangan, dan gaya luar yang terjadi akan mengakibatkan material mengalami tegangan. Sebuah 
material yang dikenai beban atau gaya akan mengalami deformasi, pada pembebanan di bawah titik leleh deformasi akan kembali hilang. Hal ini disebabkan karena material memiliki sifat elastis (elastic zone).

Jika beban ditingkatkan sampai melewati titik leleh (yield point), maka deformasi akan terjadi secara permanen atau terjadi deformasi plastis (plastic deformation). Jika beban ditingkatkan hingga melewati tegangan maksimal, maka material akan mengalami patah.

Tegangan adalah besaran pengukuran intensitas gaya atau reaksi dalam yang timbul persatuan luas. Tegangan dibedakan menjadi dua yaitu engineering stress dan true stress (Marciniak dkk, 2002). Dalam praktek teknik, gaya umumnya diberikan dalam pound atau newton, dan luas yang menahan dalam inch ${ }^{2}$ atau $\mathrm{mm}^{2}$. Akibatnya tegangan biasanya dinyatakan dalam pound/inch ${ }^{2}$ yang sering disingkat psi atau Newton/mm ${ }^{2}$ (MPa). Tegangan yang dihasilkan pada keseluruhan benda tergantung dari gaya yang bekerja.

Pada saat benda menerima beban sebesar $P \mathrm{~kg}$, maka benda akan bertambah panjang sebesar $\Delta L \mathrm{~mm}$. Saat itu pada material bekerja tegangan yang dapat dihitung dengan rumus (engineering stress):

$$
\text { бeng }=\frac{F}{A_{0}}
$$

dengan $\sigma_{\text {eng }}=$ Engineering stress (pascal, $\mathrm{N} / \mathrm{m}^{2}, \mathrm{MPa}$ ), $F=$ beban yang diberikan (Newton, dyne), $\mathrm{A}_{0}=$ luas penampang mula-mula $\left(\mathrm{mm}^{2}\right)$

Sedangkan true stress adalah tegangan hasil pengukuran intensitas gaya reaksi yang dibagi dengan luas permukaan sebenarnya (actual). True stress dapat dihitung dengan:

$$
\sigma=\frac{F}{A}
$$

$\sigma=$ True stress (pascal, $\left.\mathrm{N} / \mathrm{m}^{2}, \mathrm{MPa}\right), F=$ Gaya $($ Newton $), A_{0}=$ luas permukaan sebenarnya $\left(\mathrm{mm}^{2}\right)$

Regangan didefinisikan sebagai perubahan panjang material dibagi panjang awal akibat gaya tarik ataupun gaya tekan pada material. Batasan sifat elastis perbandingan regangan dan tegangan akan linier dan akan berakhir sampai pada titik mulur. Hubungan tegangan dan regangan tidak lagi linier pada saat material mencapai batasan fase sifat plastis. Regangan dibedakan menjadi dua, yaitu: engineering strain dan true strain (Marciniak dkk, 2002).

$$
\varepsilon_{\text {eng }}=\frac{l-l o}{l o} \times 100 \%=\frac{\Delta l}{l o} \times 100 \%
$$

$\varepsilon_{\mathrm{eng}}=$ Engineering strain, $\Delta \mathrm{l}=$ Perubahan panjang, $\mathrm{l}=$ = panjang mula-mula, $\mathrm{l}=$ Panjang setelah diberi gaya

Deformasi atau perubahan bentuk terjadi apabila bahan dikenai gaya. Selama proses deformasi berlangsung, material menyerap energi sebagai akibat adanya gaya yang bekerja. Sebesar apapun gaya yang bekerja pada material, material akan mengalami perubahan bentuk dan dimensi. Perubahan bentuk secara fisik pada benda dibagi menjadi dua, yaitu deformasi plastis dan deformasi elastis. Penambahan beban pada bahan yang telah mengalami kekuatan tertinggi tidak dapat dilakukan, karena pada kondisi ini bahan telah mengalami deformasi total. Jika beban tetap diberikan maka regangan akan bertambah dimana material seakan menguat yang disebut dengan penguatan regangan (strain hardening) yang selanjutnya benda akan mengalami putus pada kekuatan patah.

\section{METODE ELEMEN HINGGA}

Metode elemen hingga (finite element method) adalah metode numeris untuk penyelesaian masalah teknik dan fisika matematis. Masalah-masalah tersebut meliputi analisa struktur, heat transfer, aliran fluida, perpindahan massa, dan elektromagnetik. Selain penyelesaian dengan metode numeris, terdapat penyelesaian dengan metode matematis. Untuk permasalahan kompleks dari geometri pembebanan, dan sifat material, umumnya akan sulit untuk menyelesaikannya secara matematis. Alternatif metodenya adalah dengan cara membagi kasus tadi menjadi bagianbagian kecil yang sederhana yang mana pada bagian kecil tersebut kita bisa membangun model matematik dengan lebih sederhana. Kemudian interaksi antar bagian kecil tersebut ditentukan berdasarkan fenomena fisik yang akan diselesaikan. Metode ini dikenal sebagi metode elemen hingga, karena kita membagi permasalahan menjadi sejumlah elemen tertentu (finite) untuk mewakili permasalah yang sebenarnya jumlah elemennya adalah tidak berhingga (kontinum). 
Langkah-langkah umum Metode Elemen Hingga terbagi menjadi 8 (delapan) yang meliputi:

1. Diskritasi/meshing dan pemilihan jenis elemen

2. Memilih Fungsi Perpindahan (Displacement Function)

3. Menentukan Persamaan Hubungan antara Regangan dan Deformasi serta antara tegangan dan Regangan

4. Menentukan Matriks Persamaan dan Kekakuan Elemen

5. Penggabungan Persamaan Elemen Pembentuk Persamaan Global/ Total dari Sistem dan Menentukan Batas Syarat

6. Menyelesaikan Derajat Kebebasan yang Tidak Diketahui

7. . Menghitung harga tegangan dan regangan pada elemen

8. . Menginterpretasikan hasil

\section{ELEMEN SHELL}

Sebuah elemen shell adalah sejenis elemen struktur yang dicirikan oleh bentuk geometrinya, yaitu berbentuk padatan tiga dimensi yang ketebalannya sangat kecil bila dibandingkan dengan dimensi lainnya. Pada dasarnya, elemen shell adalah elemen gabungan dari elemen membrane dan elemen pelat, yaitu elemen yang memiliki tahanan in-plane dan out-of-plane, mampu menahan lentur, namun juga mampu menahan tekan. Elemen shell memiliki 6 degree of freedom (d.o.f), yaitu 3 translasi ( $\operatorname{arah} \mathrm{x}, \mathrm{y}$, dan $\mathrm{z}$ ) serta $3 \operatorname{rotasi}(\operatorname{arah} \mathrm{x}, \mathrm{y}, \mathrm{dan} \mathrm{z}$ ).

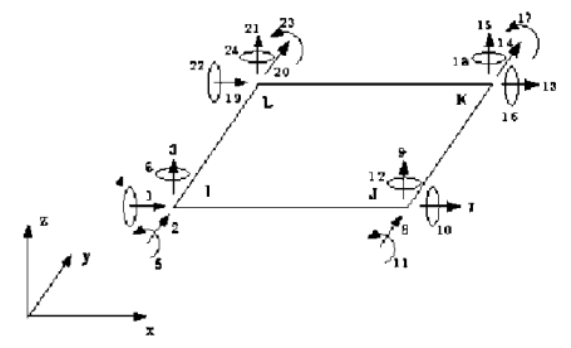

Gambar 2. Elemen Shell

\section{STUDI KASUS}

Analisis dilakukan pada balok tanpa lubang dan rhomb atau balok baja dengan bukaan belah ketupat dengan bantuan program SAP2000 versi 19. Balok yang akan dianalsis memiliki bentang $900 \mathrm{~mm}$ dengan mutu baja BJ 41 (tegangan leleh, $\mathrm{Fy}=250 \mathrm{MPa}$ dan tegangan ultimate, $\mathrm{Fu}=410 \mathrm{Mpa}$ ) dan tegangan elastis $\mathrm{E}=200.000 \mathrm{MPa}$. Profil baja yang digunakan sebagai induk merupakan baja IWF dengan ketinggian $120 \mathrm{~mm}, 125 \mathrm{~mm}$, dan $130 \mathrm{~mm}$ yang akan dimodelkan menjadi 6 (enam) jenis rhomb dengan ukuran yang berbeda-beda. Hal yang menjadi pembeda pada masing-masing rhomb tersebut adalah perbandingan tinggi keseluruhan dengan tinggi bukaan (D/Do) yaitu 1.27, $1.33,1.41,1.50,1.61$, dan 1.75. Beban yang digunakan dalam analisis terbagi menjadi 2 (dua) yaitu sebuah beban terpusat yang terletak pada tengah bentang dan 2 (dua) buah beban terpusat berjarak $300 \mathrm{~mm}$ yang terletak di tengah bentang. Kedua beban tersebut bernilai $1000 \mathrm{~N}$ yang diletakan pada bagian flens atas pada rhomb tersebut.

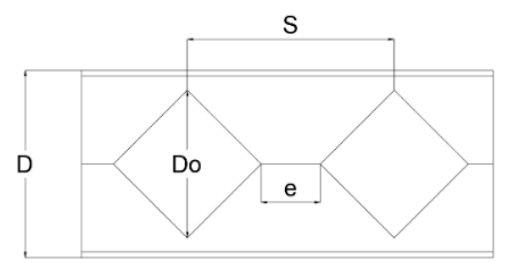

Gambar 3. Terminologi dasar Rhomb 
Jurnal Mitra Teknik Sipil

Vol. 1, No. 1, Agustus 2018: hlm 55-64

Tabel 1. Parameter yang digunakan untuk Rhomb

\begin{tabular}{|c|c|c|c|c|c|c|c|}
\hline $\begin{array}{c}\text { Model } \\
\text { No }\end{array}$ & $\begin{array}{c}\text { Do } \\
(\mathrm{mm})\end{array}$ & $\begin{array}{c}\mathrm{D} \\
(\mathrm{mm})\end{array}$ & D/Do & S/Do & $\begin{array}{c}\mathrm{S} \\
(\mathrm{mm})\end{array}$ & $\begin{array}{c}\mathrm{e} \\
(\mathrm{mm})\end{array}$ & $\begin{array}{c}\% \text { lubang } \\
(\%)\end{array}$ \\
\hline 1 & 130 & 165 & 1.27 & 1.4 & 182 & 52 & 22.76 \\
\hline 2 & 120 & 160 & 1.33 & 1.4 & 168 & 48 & 20 \\
\hline 3 & 110 & 155 & 1.41 & 1.4 & 154 & 44 & 21.69 \\
\hline 4 & 100 & 150 & 1.5 & 1.4 & 140 & 40 & 22.22 \\
\hline 5 & 90 & 145 & 1.61 & 1.4 & 126 & 36 & 18.62 \\
\hline 6 & 80 & 140 & 1.75 & 1.4 & 112 & 32 & 17.78 \\
\hline
\end{tabular}

Pemodelan rhomb, pembebanan, dan spesifikasi yang digunakan pada rhomb di atas didasarkan pada penelitian yang telah dilakukan sebelumnya oleh Jamadar A. M. dan Kumbhar P. D. dalam International Research Journal of Engineering and Technology (IRJET) volume: 02 Issue:02. Penelitian tersebut telah dilakukan secara analisis numerik maupun melalui praktikum.

Analisis dilakukan dengan menganggap sambungan las rigid 100\% serta dilakukan dalam tahap baja masih mengalami elastis. Selain itu elemen-elemen dibagi atau didiskritisasi menjadi elemen shell dengan pembebanan yang telah disebutkan di atas. Analisis dilakukan dengan bantuan program SAP2000 versi 19 dan akan dilakukan peninjauan terhadap tegangan lentur, tegangan geser, dan defleksi yang terjadi pada masing-masing rhomb.

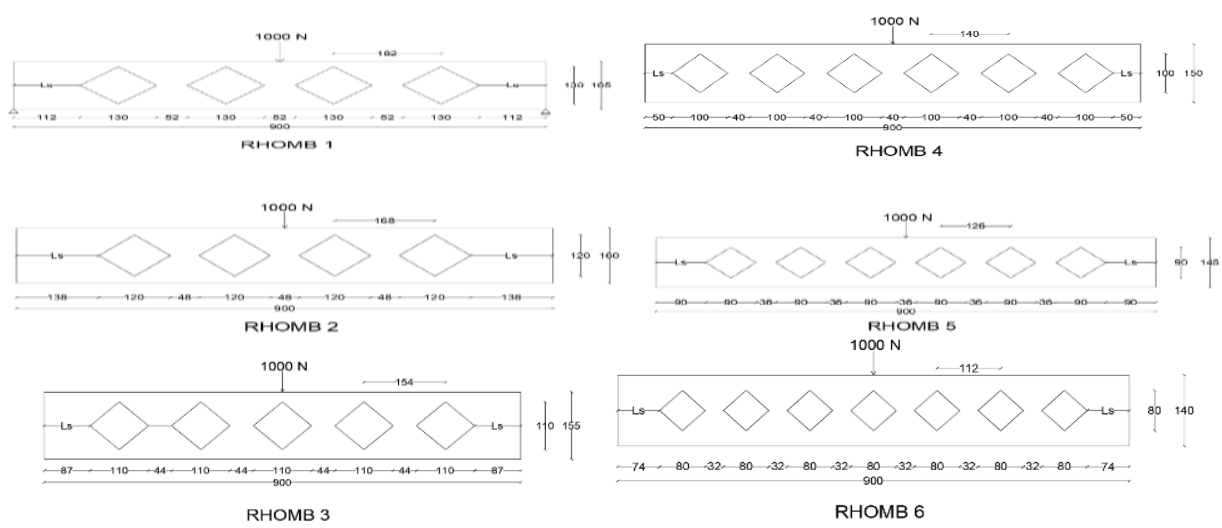

Gambar 4. Pemodelan Rhomb

\section{Tegangan Lentur}

Setelah membuat pemodelan sturktur pada program SAP2000 selanjutnya dilakukan pembacaan hasil terhadap nilai tegangan lentur $\left(\mathrm{S}_{11}\right)$ dari masing-masing balok pada beberapa titik pada setiap rhomb

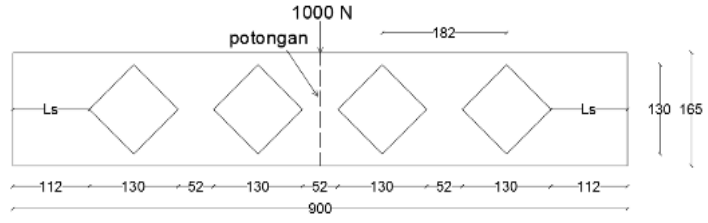

RHOMB 1

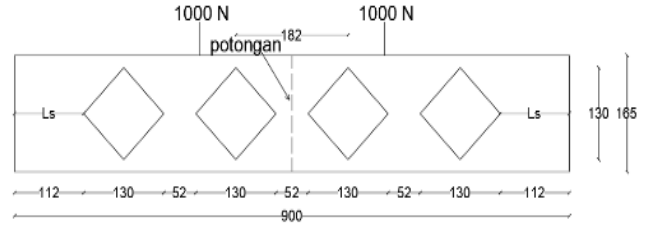

RHOMB 1

Gambar 5. Letak Peninjauan Tegangan Lentur 

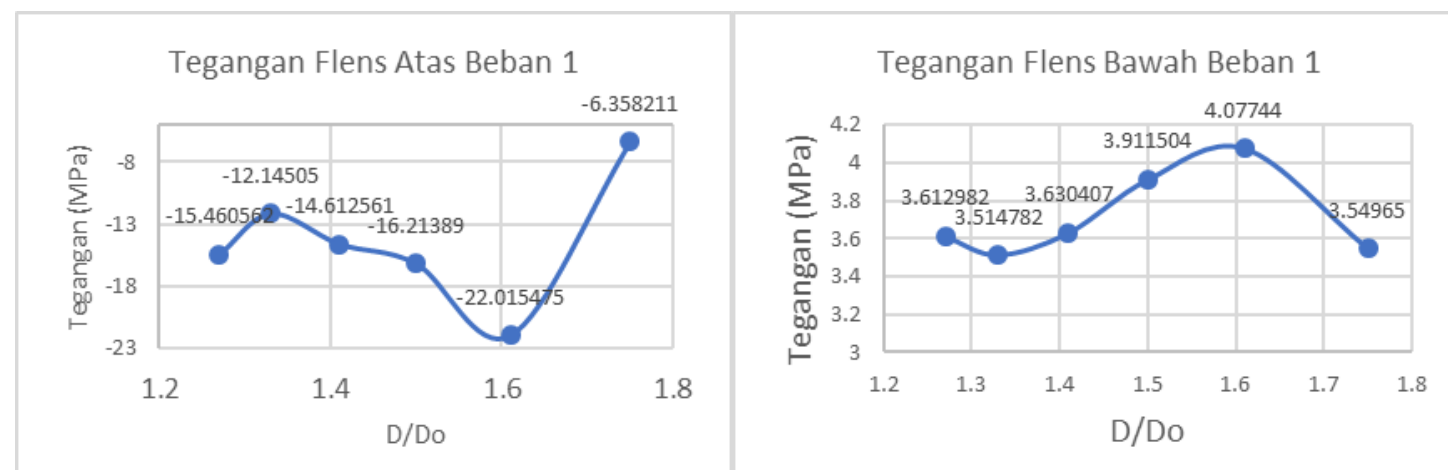

Gambar 6. Perbandingan Tegangan Lentur Flens Atas dan Bawah Beban 1

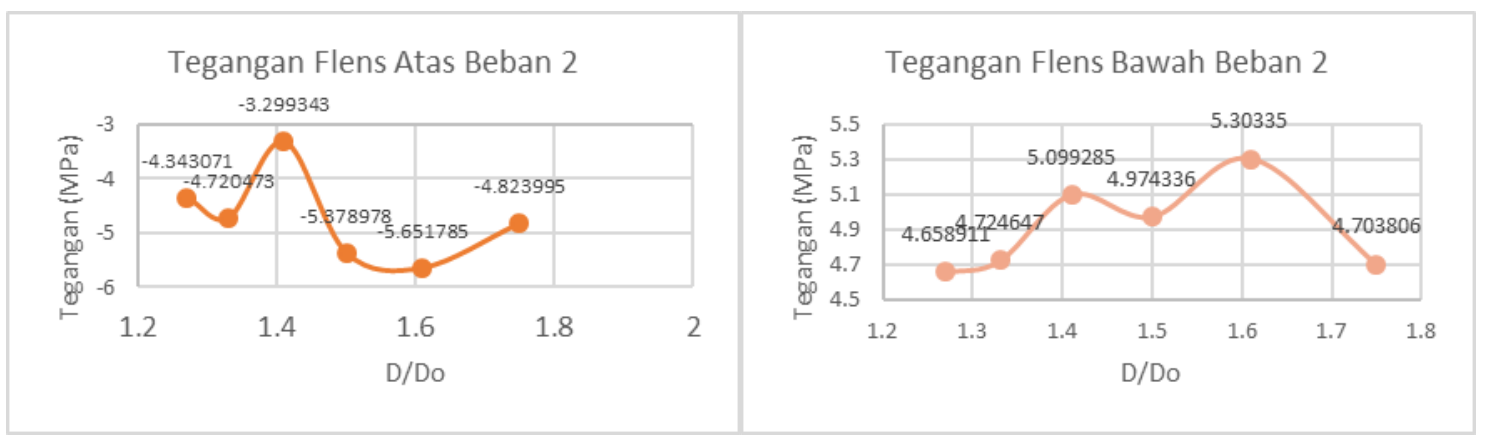

Gambar 7. Perbandingan Tegangan Lentur Flens Atas dan Bawah Beban 2

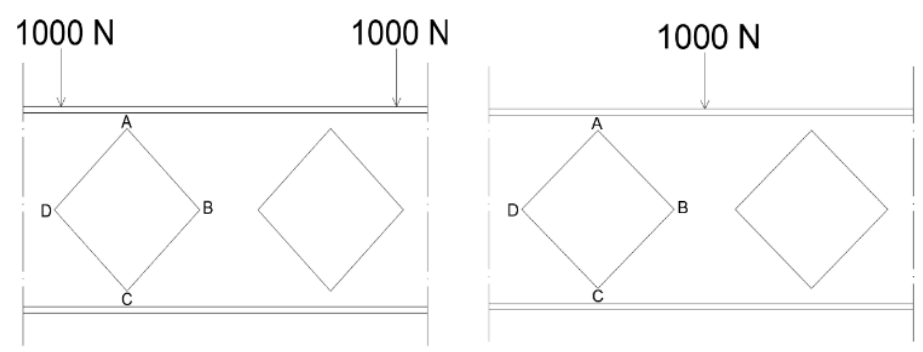

Gambar 8. Letak Peninjauan Tegangan Lentur pada Bukaan

Tabel 2. Tabel Perbandingan Tegangan Lentur Beban 1 Rhomb dengan Balok Tanpa Bukaan

\begin{tabular}{|c|c|c|c|c|c|}
\hline \multicolumn{3}{|c|}{ BEBAN 1 } & \multicolumn{3}{|c|}{ BEBAN 1 } \\
\hline \multirow{2}{*}{ TITIK BUKAAN } & \multicolumn{2}{|c|}{ TEGANGAN (MPA) } & \multirow{2}{*}{ TITIK BUKAAN } & \multicolumn{2}{|c|}{ TEGANGAN (MPA) } \\
\cline { 2 - 3 } & BALOK 1 & RHOMB 1 & & BALOK 4 & RHOMB 4 \\
\hline A & -1.977706 & -3.726571 & A & -2.06088 & -2.899641 \\
\hline B & 0.127721 & -0.08345 & B & -0.129113 & -0.307917 \\
\hline C & 1.954576 & 3.537151 & C & 1.870839 & 2.231874 \\
\hline D & 0.127726 & -0.398073 & D & -0.373295 & -0.209268 \\
\hline
\end{tabular}


Jurnal Mitra Teknik Sipil

Vol. 1, No. 1, Agustus 2018: hlm 55-64

Tabel 2. Tabel Perbandingan Tegangan Lentur Beban 1 Rhomb dengan Balok Tanpa Bukaan (Lanjutan)

\begin{tabular}{|c|c|c|c|c|c|}
\hline \multicolumn{3}{|c|}{ BEBAN 1} & \multicolumn{3}{|c|}{ BEBAN 2} \\
\hline \multirow{2}{*}{ TITIK BUKAAN } & \multicolumn{2}{|c|}{ TEGANGAN (MPA) } & \multirow{2}{*}{ TITIK BUKAAN } & \multicolumn{2}{|c|}{ TEGANGAN (MPA) } \\
\hline & BALOK 2 & RHOMB 2 & & BALOK 5 & RHOMB 5 \\
\hline $\mathrm{A}$ & -2.29403 & -2.937926 & A & -3.140754 & -6.127856 \\
\hline $\mathrm{B}$ & 0.141015 & -0.080028 & $\mathrm{~B}$ & 0.231473 & 0.10089 \\
\hline $\mathrm{C}$ & 2.285252 & 2.091484 & $\mathrm{C}$ & 2.657559 & 4.593162 \\
\hline $\mathrm{D}$ & 0.141015 & -0.060414 & $\mathrm{D}$ & 0.231634 & -0.304351 \\
\hline \multicolumn{3}{|c|}{ BEBAN 1} & \multicolumn{3}{|c|}{ BEBAN 1} \\
\hline \multirow{2}{*}{ TITIK BUKAAN } & \multicolumn{2}{|c|}{ TEGANGAN (MPA) } & \multirow{2}{*}{ TITIK BUKAAN } & \multicolumn{2}{|c|}{ TEGANGAN (MPA) } \\
\hline & BALOK 3 & RHOMB 3 & & BALOK 6 & RHOMB 6 \\
\hline $\mathrm{A}$ & -1.899371 & 2.40455 & $\mathrm{~A}$ & -1.928074 & -2.125889 \\
\hline $\mathrm{B}$ & -0.041568 & -1.98022 & $\mathrm{~B}$ & 0.048663 & -1.310874 \\
\hline $\mathrm{C}$ & 2.714885 & 5.963792 & $\mathrm{C}$ & 2.354615 & 5.327522 \\
\hline $\mathrm{D}$ & -0.041559 & -1.980791 & $\mathrm{D}$ & 0.048666 & -1.310899 \\
\hline
\end{tabular}

Tabel 3. Tabel Perbandingan Tegangan Lentur Beban 2 Rhomb dengan Balok Tanpa Bukaan

\begin{tabular}{|c|c|c|c|c|c|}
\hline \multicolumn{3}{|c|}{ BEBAN 2} & \multicolumn{3}{|c|}{ BEBAN 2} \\
\hline \multirow{2}{*}{ TITIK BUKAAN } & \multicolumn{2}{|c|}{ TEGANGAN (MPA) } & \multirow{2}{*}{ TITIK BUKAAN } & \multicolumn{2}{|c|}{ TEGANGAN (MPA) } \\
\hline & BALOK 1 & RHOMB 1 & & BALOK 4 & RHOMB 4 \\
\hline $\mathrm{A}$ & -3.578127 & -5.501595 & $\mathrm{~A}$ & -3.046 & -4.521287 \\
\hline $\mathrm{B}$ & 0.216471 & -1.136081 & $\mathrm{~B}$ & -0.313953 & -0.312934 \\
\hline $\mathrm{C}$ & 3.475649 & 6.126754 & $\mathrm{C}$ & 2.876084 & 3.610374 \\
\hline $\mathrm{D}$ & 0.216148 & -0.34415 & $\mathrm{D}$ & -0.721229 & 0.275468 \\
\hline \multicolumn{3}{|c|}{ BEBAN 2} & \multicolumn{3}{|c|}{ BEBAN 1} \\
\hline \multirow{2}{*}{ TITIK BUKAAN } & \multicolumn{2}{|c|}{ TEGANGAN (MPA) } & \multirow{2}{*}{ TITIK BUKAAN } & \multicolumn{2}{|c|}{ TEGANGAN (MPA) } \\
\hline & BALOK 2 & RHOMB 2 & & BALOK 5 & RHOMB 5 \\
\hline A & -3.716921 & -5.941128 & A & -2.235252 & -3.327561 \\
\hline $\mathrm{B}$ & -0.148104 & -0.232832 & $\mathrm{~B}$ & 0.194968 & -0.205352 \\
\hline $\mathrm{C}$ & 3.646728 & 4.137958 & $\mathrm{C}$ & 2.004024 & 3.130521 \\
\hline $\mathrm{D}$ & -0.150854 & -0.2683 & $\mathrm{D}$ & 0.196126 & -0.748816 \\
\hline
\end{tabular}

\begin{tabular}{|c|c|c|c|c|c|}
\hline \multicolumn{3}{|c|}{ BEBAN 2 } & \multirow{3}{*}{ BEBAN 2 } \\
\hline \multirow{2}{*}{ TITIK BUKAAN } & \multicolumn{2}{|c|}{ TEGANGAN (MPA) } & \multirow{2}{*}{ TITIK BUKAAN } & \multicolumn{2}{|c|}{ TEGANGAN (MPA) } \\
\cline { 2 - 3 } & BALOK 6 & RHOMB 6 & & BALOK 3 & RHOMB 3 \\
\hline A & -3.208188 & -6.460542 & $\mathrm{~A}$ & -3.73518 & -8.342537 \\
\hline B & 0.257966 & 0.106432 & $\mathrm{~B}$ & -0.045749 & 0.820293 \\
\hline $\mathrm{C}$ & 3.166292 & 4.299315 & $\mathrm{C}$ & 3.575952 & 3.218042 \\
\hline $\mathrm{D}$ & 0.257931 & 0.106421 & $\mathrm{D}$ & -0.044105 & 0.824938 \\
\hline
\end{tabular}

\section{Tegangan Geser}

Setelah melakukan analisis terhadap tegangan lentur maka selanjutnya dilihat hasil analisis pengaruh perbandingan tinggi profil (D) terhadap tinggi bukaan (Do) terhadap tegangan geser $\mathrm{S}_{12}$. Hasil analisis ditinjau dari titik titik yang terdapat pada bukaan yang terletak dekat dengan tengah bentang dan dekat dengan perletakan
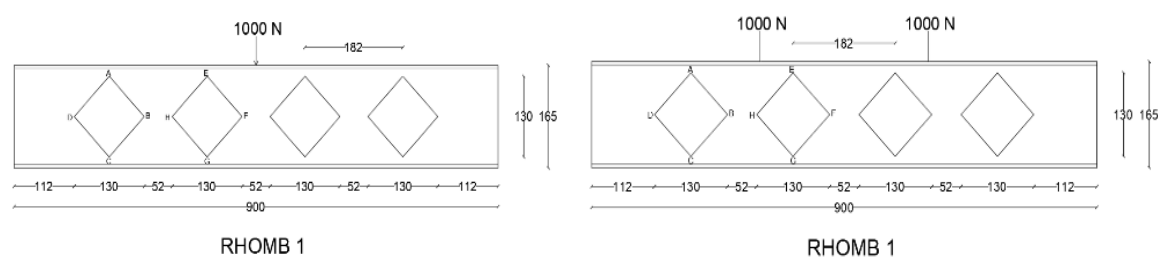

Gambar 9. Letak Peninjauan Tegangan Geser 

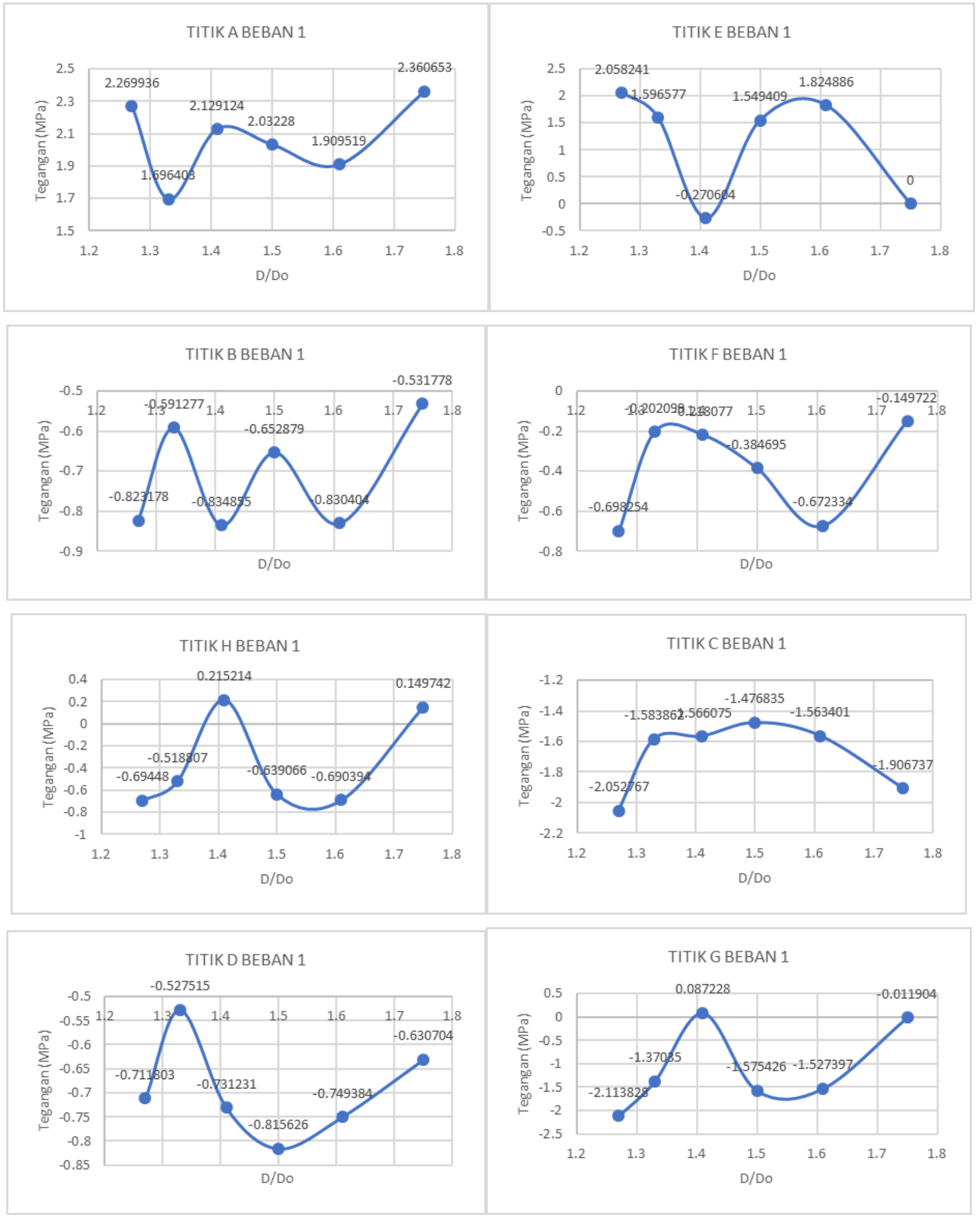

Gambar 10. Hasil Tegangan Geser pada Bukaan Beban 1 

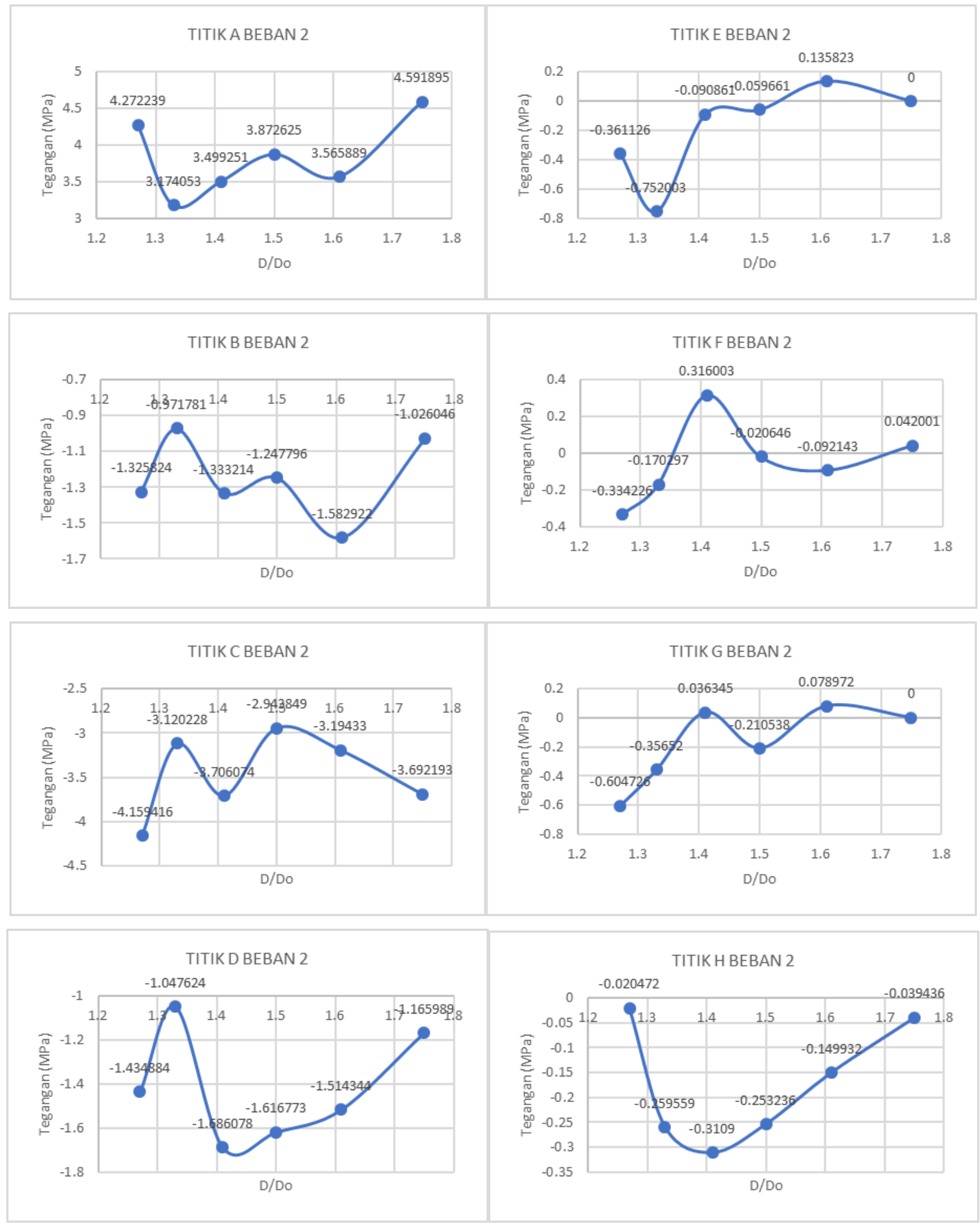

Gambar 11. Hasil Tegangan Geser pada Bukaan Beban 2 


\section{Defleksi}

Setelah dilakukan analisis terhadap nilai tegangan lentur dan tegangan geser yang terjadi, dilanjutkan analisis terhadap nilai defleksi pada tengah bentang setiap balok. Hasil analisis didapatkan dari output program SAP2000 versi 19 dengan pembacaan U3 dalam satuan milimeter (mm).

Tabel 4. Tabel Hasil Defleksi Beban 1 dan Beban

\begin{tabular}{|c|c|c|c|}
\hline \multicolumn{2}{|c|}{ Beban 2 } & \multicolumn{2}{c|}{ Beban 1 } \\
\hline \multirow{2}{*}{ D/Do } & Defleksi pada Tengah Bentang (mm) & D/Do & Defleksi pada Tengah Bentang (mm) \\
\hline 1.27 & -0.039276 & 1.27 & -0.026202 \\
\hline 1.33 & -0.038283 & 1.33 & -0.024802 \\
\hline 1.41 & -0.043758 & 1.41 & -0.025196 \\
\hline 1.5 & -0.045952 & 1.5 & -0.028495 \\
\hline 1.61 & -0.047352 & 1.61 & -0.029023 \\
\hline 1.75 & -0.047057 & 1.75 & -0.028314 \\
\hline
\end{tabular}

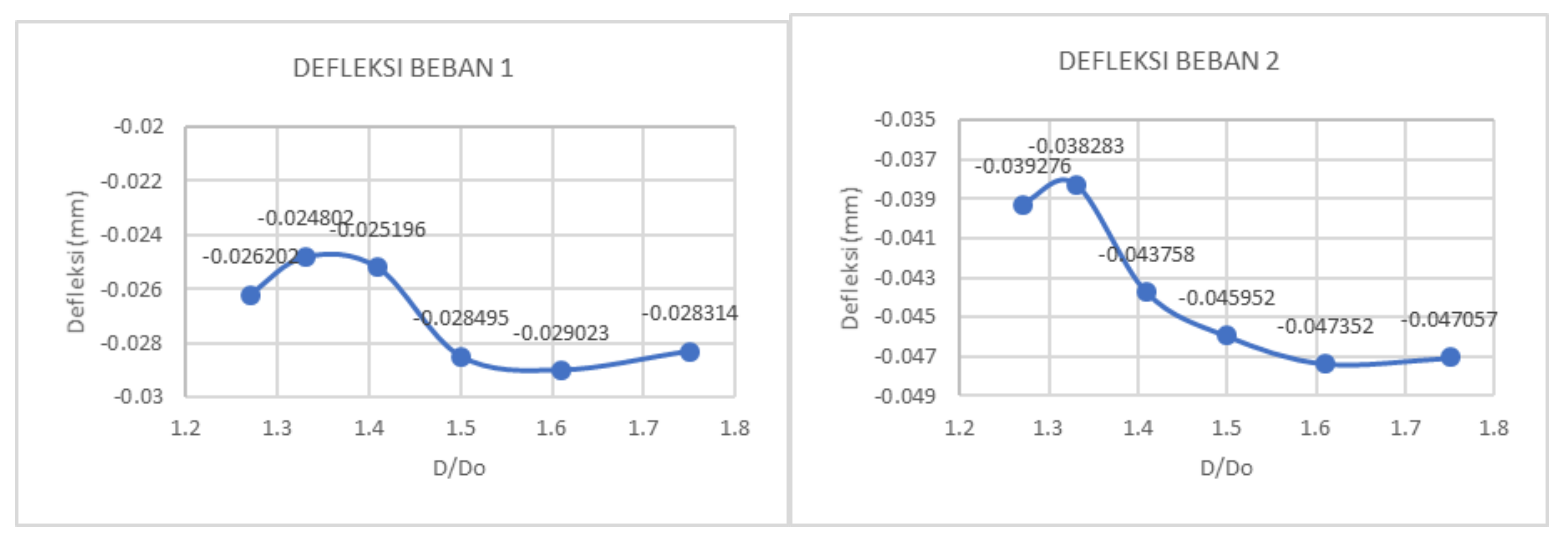

Gambar 12. Hasil Defleksi Beban 1 dan Beban 2

\section{KESIMPULAN}

1. Pengaruh D/Do terhadap tegangan lentur bervariatif. Berdasarkan hasil tersebut ditemukan bahwa nilai perbandingan D/Do 1.61 merupakan rhomb terlemah karena tegangan lentur pada serat atas dan serat bawah yang terjadi merupakan yang terbesar.

2. Dengan pembebanan yang sama, pengaruh perbandingan D/Do terhadap tegangan geser bervariatif, namun ditemukan pada umumnya perbandingan D/Do 1.27 merupakan rhomb dengan nilai tegangan terbesar dibandingkan perbandingan D/Do lainnya.

3. Dari hasil analisis terlihat bahwa dengan pembebanan yang sama, semakin besar perbandingan D/Do maka defleksi yang terjadi semakin besar yang menyebabkan rhomb semakin lemah.

4. Pada daerah bukaan terjadi konsentrasi tegangan yang lebih besar hingga 2 (dua) kali dibandingkan dengan balok induknya.

5. Pada area yang diletakan beban terjadi lonjakan tegangan yang tinggi (disturbed area) sehingga daerah tersebut hasilnya akan sulit untuk dianalisis.

\section{DAFTAR PUSTAKA}

Amayreh, L., and M. P. Saka. Failure Load Prediction of Castellated Beams Using Artificial Neural Networks. Asian Journal of Civil Engineering (Building and Housing). Vol. 6. No. 1-2 (2005): 35-54

Blodgett, Omer W. Open-Web Expanded Beams and Girders (Design of Welded Structures). Ohio: The James F. Lincoln Arc Welding Foundation, 1982.

Eric. Analisis Pengaruh Sudut Pemotongan pada Castellated Beam dengan Metode Elemen Hingga. Skripsi. Jakarta: UNTAR, 2017

M. Jamadar A., and D. Kumbhar P. Parametric Study of Castellated Beam with Circular and Diamond Shaped Openings. International Research Journal of Engineering and Technology (IRJET). Vol.2, Issue 2, 2015. 